\title{
Revisiting the Meaning of Yekaterinburg City Name
}

\author{
Leonid S. Chernov ${ }^{\text {a* }}$ \\ and Elena Iu. Pogorel'skaia ${ }^{\text {b* }}$ \\ ${ }^{a}$ Urals Institute of Administration of RANEPA \\ 66 Marta 8 Str., Yekaterinburg, 620063, Russia \\ ${ }^{b}$ Humanitarian University of Yekaterinburg \\ 19 Studencheskaya Str., Yekaterinburg, 620049, Russia
}

Received 18.07.2016, received in revised form 29.07.2016, accepted 28.08.2016

The paper raises the problem of the city symbol. Authors show the deep metaphysical connection behalf of the city with historical events and facts of history of Ekaterinburg. The city appears here as a living organism and personality. The part of the work is semiotic and iconographic illustration of ideas and theses of this research.

Keywords: Yekaterinburg, symbol, name, skill, Saint Catherine, walled city, ideal city, Catherine icon, Women spinner, betrothal to Christ.

DOI: 10.17516/1997-1370-2016-9-9-2114-2121.

Research area: theory and history of culture.

There will be more chance of finding correctness in the names of immutable essences; there ought to have been more care taken about them when they were named, and perhaps there may have been some more than human power at work occasionally in giving them names ${ }^{1}$.

Plato

Urban ontology research often sets the city symbol issue. For instance, symbolic reality of Saint Petersburg is more than just commemoration of Peter the Great, it is connected "with the idea of Petersburg as a New Rome. Orientation on Rome reveals itself not only in the name of this capital, but also in its coat of arms: it contains some transformed motives of that of Rome (or Vatican as the successor of Rome), which is, indeed, not a coincidence". ${ }^{2}$ Therefore, when an issue of symbolic reality, which always follows the external, variable and historically diverse form, is set, the metaphysical core of the phenomenon needs to be found. This Aristotle-like approach seems reasonable because it draws attention to the fact that a cultural establishment, which a city doubtlessly is, needs some basis for existence and continue of its history. No matter how strange it sounds, but the city symbol issue is a practical question, though it looks purely theoretical and

(c) Siberian Federal University. All rights reserved

* Corresponding author E-mail address: leon-chernov@yandex.ru; schreibigus@mail.ru 
based only on the value of the truth, which is the truth for the sake of the truth as such. However, as a polity, as a totality of institutional forms and processes administration is carried out through, a city needs to realize its symbolic reality, which is the base for its practical activity, because it is where the real and the most powerful source for development belongs.

A lot has been written about cities in general; however, the city symbol always remains "out of vision". Taking everything for granted, without worrying or caring of how everything is done, without seeing the sources of being, is a common thing. We can live in a city without the urge to understand or even to ask a question, how to understand it. It happens in life in general and in language in particular: we live, we speak, without being aware of what and how is going on. Perhaps, the reason is the fact that the visible and continuously changing being of the city is naturally excessive in regard with its invisible gist. Therefore, a city is continuously reproduced as a sort of collective social being.

We suggest that every city exists as individuality; it has its face, its inherent entelechy, and completeness which unwinds in the tradition of the city, or, to be even more precise, in the city symbol. A symbol is due to exist as a real definition, as a current being of the city, which differs one city from another, this face from many others. Since a thing has a name which has been given to it from the beginning to express its distinctive characteristics, this name contains a certain reality which may be deciphered and understood. Though some historical events have not happened yet, they have been programmed in the name as set in stone.

The city was founded in 1723. Contemporary historians write: "It was Yekaterinburg, an industrial capital, built as though in compliance with a "perfect fortress" plan, the main city of the region established for ages. From now on, new factories could be built and old ones could die, the need for fortresses could disappear, provinces could change their boundaries and the region could change its name, but Yekaterinburg had to remain what it had been meant to be: the capital of the Urals"3. When a city begins from a fortress, it assumes that the place needs some protection, that it is valuable and special. The fortress is intended to make the place powerful and strong. A planned fortress is a result of rational thinking which starts from understanding of the reasonability and necessity for such an establishment. Perfect planning is an argument to the metaphysical reality. Factories, temples, squares, and houses could be built inside; but the main thing that mattered was the security, both physical, the strong walls, and metaphysical, which is the power of the divine protector. For this reason, right from the establishment of the fortress walls on March 12, 1723, the Church of St. Catherine was founded. It means that the city was built on two levels: literal, or physical, and ideal, or metaphysical.

According to the legend, the name for the city was suggested by Georg Wilhelm de Hennin, who was a specialist in mining and metallurgy, a friend and an ally of Peter the Great. "Willing to please the Tsar, Hennin decided to name the new factory after his wife, Empress Catherine the Great, and the idea was approved. On October 1,1723 , on the left bank of the Iset River, the foundation of a wattle church named after the Holy Great Martyr Catherine was laid, and on November 24 the first nameday of the fortress factory was celebrated, and cannons fired from the fortress walls..."4

The name of the city is its "genetic centre", or the "core cell", as Pavel Florenskiy said. It is a point of active development. It is the presence of a name, a proper name, which establishes the living core of a thing. Let's recall the Biblical story of Adam. God gave Adam the blessing of 
callinng every creature by name, to give names to animals and plants. As long as nature obeyed Adam, Adam was the first to give out names, and the names had a "proper" character. However, later the humankind lost the "obedient and free submission of nature" and the names turned into common names, or simple denotation. But proper names remained where they belonged: in speech, in literal use, in documents; they still exist and live the same way as they were when they were first created. A.F. Losev says, "The name of a thing is the thing itself"', meaning that something seemingly "small" may be a principal statement of something "large". Calling someone, we call his real self by name. The name refers to the total of a creature. When a baby is born, the first thing it is given is a name. Its first document, the birth certificate, contains only three facts: the name of the newborn, the time of birth and the names of parents. Of course, later comes the passport and other documents, but they are just an expansion of the name's influence. The same is true for a city. It is important when a city is founded; this fact will be mentioned in chronicles, documents, certificates. It matters, who the founder was: an emperor, a tsar, or a prophet. At last, it is the name of the city that matters. As Saint Ambrose of Optina said, "Name determines living". Wise governors are always careful about choosing a name for a new city.

For example, appearance of the modern capital of Kazakhstan was mostly the personal choice of its president, N. Nazarbaev. He chose the place and territory of the Soviet Tselinograd, but, of course, did not keep the Soviet name as empty, exhausted, and futureless for the history of Kazahstan. But N. Nazarbaev could also "keep", return the previous name of the place, the beautiful Kazakh name "Akmola" and give it to the capital; moreover, there are two centuries of Kazakh history standing behind it. But he chose not to do it, as Akmola is translated from Kazakh as "the White Grave", and no one would wish such a future for the capital, and, therefore, for himself. For this reason, beginning to construct new future for Kazakhstan, Nursultan Nazarbaev and all the Kazakh people named their capital Astana, which means simply "the Capital". This is the example of careful attitude of the Kazakh people to a city name, of the power they felt in it.

Thus, a symbol of a city is its Name. The name is the spiritual centre of the city as it contains the total of its further spiritual, moral, physical reformation. One of the contemporary writers intuitively grasped the main thing about a city name: "It is more than just a name. It's a program. It's a route. It's a purpose"'. And though the popular writer did not explain his words, the way he saw a name was right. The self-identification of a city is tightly connected to its name. "Who are you?" a man is asked. "I am Pavel", or "I am Andrey", the man answers. "I am Yekaterinburg", the city answers. Oblivion is scary for both a man and a city. "He lost himself", we say about a man, and it means, "he lost his face". A city also remembers himself: everything begins and remains forever. "Thus the present is not a rupture, but the retention of a past Present

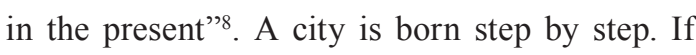
its history was just unwinding of a program, just development of a concept, it would have been a pseudo-tradition, planned development; the city would lose its freedom which is the main feature of a living being. Freedom is something excessive in every creature; it brims over, it is something extra and something "purely mine"; it is something that comes from the excess, not in exchange for something. A city has such growing points, as a city is its people who live a tradition, and any tradition is a result of an effort as any metaphysics that finds its life through a deed. "Should you continue, it shall not end", B. Pasternak says. A tradition may be regarded as an abstract concept, but any tradition finds its life 
through the performance of its purpose by man. Should one ask, which way a city needs to develop, we shall answer: the route is determined by its name. It is the name that establishes the tradition and consists of two parts: Yekaterina (Catherine) and Burg, i.e. the Fortress of Catherine.

The Holy Great Martyr Catherine, example of intransigent faith and a celestial bride, is the protectrix of mining and education. The everlasting plan of the city development is thus determined. Freedom in any development, including development of a city, assumes realization of the existing gifts and the multiplication of them. One cannot develop out of nothing and having nothing. Any growth needs some grounds. A man is free in his talent. A city is free rather as a certain tradition. Using this word, we need to understand that a tradition is not a sandcastle, a randomly chosen way with no ending or beginning. Through tradition, we can see the truth, which is there as the embryo of life. In this sense, tradition is a specific gift, which gradually unwinds into the definiteness, depositing as a real historical asset. As the founder of European phenomenology underlines, "Only the pure unity of such a tradition's sense is apt to establish this continuity. Indeed, without this no authentic history would be thought or projected as such; there would only be an empirical aggregate of finite and accidental units" .

There is no coincidence that the church of St. Catherine was immediately built in a city namedYekaterinburg. Founded on October 1,1723 , and consecrated in 1726, it was first a small wattle church. In July 1726, Empress Catherine I granted a gift to the new cathedral: some ecclesiastic attires, prayer books, gold and silver church plates. By circumstance, in 1747 the church burned down, and it was decided to lay the foundation of a new, larger stone church which would serve believers from two towns. In those times it was customary for a church to serve approximately 100 families. With the population of Yekaterinburg of over 1085 families, which is around 5726 people, the small Epiphany Cathedral which could not host even a half of the population was clearly not enough. On August 16, 1758, a new stone temple named after the Holy Great Martyr Catherine was founded. The building of St. Catherine's Church was the largest in town (approximately 1500 sq.m.), and twice as big as other large churches. In 1770, a small cemetery for the honoured citizens was arranged. From the very beginning, St. Catherine's Church was the place where mining engineers, and, starting from the $19^{\text {th }}$ century, new recruits said their vows. The Church also kept the coat of arms granted by EmperorAlexanderIItotheUrals MiningBattalion to commemorate its 100 years' anniversary, and in the early $19^{\text {th }}$ century the Church hosted a parochial school. The main relic of the Church was a part of the reliquae of the Righteous Saint Simeon of Verkhoturye. The Patron Saint's day of the Church is St. Catherine's day (November 24 O.S., December 7 N.S.) remained one of the major holidays of Yekaterinburg until the Revolution began. The square where the Church stood was named Yekaterininskaya (Catherine's Square). In March-April 1930 St. Catherine's Church was intentionally destructed by the city government $^{10}$. In the year 1988, St. Catherine's Chapel was rebuilt on the site of the destructed church to commemorate the $275^{\text {th }}$ anniversary of Yekaterinburg foundation, so the living tradition was saved.

The hagiography of the Holy Great Martyr Catherine tells the story of a feat made by a woman undaunted by the onslaught of human evil. ${ }^{11}$ Of course, one cannot stand such tortures without divine grace, but the human qualities represented by such orthodox people are the same qualities a fortress needs to possess: inviolacy, reliability, ability to counter the enemy. One of the symbols of St. Catherine is a wheel. A wheel is an 
ancient symbol present in many cultures, but for Catherine it was a torture instrument. Catherine's wheel also stands on the seal of Yekaterinburg factory.

For this reason, it seems reasonable to return to the "authentic" image of the Saint presented on the relatively early icons of Saint Catherine of Alexandria, and study the symbolism of these icon. Let's name the most famous of them. The first presents the image of Catherine with her hagiography and is traditionally dated back to the $13^{\text {th }}$ century. It is believed that this icon had been long kept in St. Catherine's Monastery on Sinai. Though not the oldest, this icon is the canonical example of depicting Catherine with her hagiography. The same icon is found today in Yekaterinburg, in the Cathedral of the Holy Trinity, in the left part of the South wall. The same picture, though without the hagiography, is found at the local liturgy of the temple. Here the icon is placed next to those of Emperor Nicholas II, St. Simeon of Verkhoturye and the Holy Great Martyr Elisabeth. It is important to emphasize that in the left part of the first row of icons there are icons of the locally venerated saints, and the saint who gave her name to the city where the temple is located. In this icon, Catherine is depicted standing, holding a crucifix in her hand, wearing a royal head dress, with the lower part of her attire decorated with a pattern of a shield and a cross. The shield makes Catherine a warrioress both metaphorically (the warrioress of faith) and literally. Catherine's face in the icon is remarkable for the strict expression and lively frankness specific for the early icons, but having nothing in common with artistic realism. The second icon is dated back to the $17^{\text {th }}$ century; it depicts Catherine sitting on the throne. Under her feet there are books, an armillary sphere (looking like a globe), in her left hand there is a palm branch and a crucifix. This icon is believed to be painted by Victor, an icon painter from Crete; variations of its copies may be found today both in Orthodox and Catholic churches. The most relevant symbolic element of this icon is the wheel Catherine leans on with her left hand, holding a crucifix and a palm branch, the symbol of victory. Other icons of the same time depict the crucifix in the right hand; with the same, right hand, the Saint is holding on a corner of a book lying on the table, her left hand with the palm branch leaning on the wheel. Except for the wheel, these symbols are easy to decipher. Since the books, sphere, crucifix and palm branch denote wisdom ${ }^{12}$, rational knowledge, death for the faith and Glory in the name of Christ, the wheel requires some more attention. On one hand, in this and other icons, as well as in other pictures this Saint is identified by the wheel, her torture instrument. The Life of Catherine tells how she was tied to the wheel and tortured in a way specially made for her. A similar episode is found in the margin of the Catherine of Alexandria icon with hagiography. But in the Greek icon of the seated Catherine the wheel reminds more of a spinning wheel than a torture instrument. Her left hand leans on the wheel, and the same hand is holding a crucifix and a palm branch. The wheel is standing on books as though on a rack, and Catherine is looking left, in the direction of her hand, and a little bit up. The line of her chlamys (coat) with its traditional fibula (a metal clasp) is extremely interesting and symbolic. The line/boundary of Catherine's coat is clearly emphasized in white, forming an irregular circle on her neck, doubling the line of her body; then it comes through the fibula, and as the chlamys is rested upon her shoulders, half-closing the arms, the line goes further to the left hand, circling on the wrist which touches the wheel. As a result, the lower boundary of the coat visible to us forms a line which goes from the palm branch in the left hand to the wheel, the fibula, and the right hand holding nothing, though looking as though grasping a thread coming from the wheel. At first 
sight Catherine seems to be holding a spindle; but we see that there is no spindle and it is an illusion created by the line. However, the slight left-ward movement seen in the icon, the way the left hand is leaning on the wheel and the coat line forming a distinctive thread create an image of a spinner with a spindle in her right hand and a flax tow (fibre) looking like a palm branch. As a result, the icon has a specific character. Martyrdom on the cross, as the cross and the wheel are often interchangeable as local symbols, is turned into productive work of a spinner, making yarn of the Grace of Christ (the palm branch).

Generally, Western researchers identify Russia with the female principle and say that the soul of Russia is that of a woman. Accepting these theses formally, Yekaterinburg with the female image in the centre of its symbol proves this suggestion. But what "female" soul is assumed by the Western authors? As a rule, the female principle in their concepts means weakness, flexibility, shapelessness, compliance, instability, irrationality and, consequently, inert inconsistent compassion and unproductive kindness. But is it really so? In the name of Catherine we find different properties of a female character, and Russian literature also speaks of a different sort of femininity: "with the posture and sight of a queen". And the fact that women like the Holy Great Martyr Catherine "can stop a galloping horse", is the continue of that huge spiritual power which may be discreet under the seeming quietness.

Tales by P.P. Bazhov present a female image of the Mistress of the Copper Mountain, the Mistress of the Urals. This image shows no weakness or tearfulness, sentimentality or shapelessness. The Mistress is very determined, she clearly instructs her craftsmen of what she wants to be done; she knows how to demand, and first of all, she demands her craftsman to give all his spiritual might to the full. The worst betrayal is the betrayal of one's talent, a gift which needs to grow. We may suppose that the severe Mistress of the Ural Mountains is a folklore incarnation of St. Catherine, and this character does have a "metal orientation". In fact, Peter the Great intended to bring up a special kind of people in the Urals, which would be hard as nails and stone.

In the $20^{\text {th }}$ century Yekaterinburg became the Ural Calvary. There is an inexplicable connection between the facts that Jerusalem was the place where Christ was crucified, and Yekaterinburg was the place of execution of the last Russian Tsar and his family. The ambivalence of the symbol of the Holy Great Martyr Catherine suggests that this land is connected with suffering. It is not a coincidence that Catherine is a Martyr.

Pavel Florenskiy writes: "In public consciousness, names are distributed into groups. If a priest names a baptizand after a Venerable, it promises him or her a happy life; if a priest names him or her after a Martyr, the life will also be a torture. It is common for a name to emphasize royalty, care for the poor and other qualities in it. Yes, in a name, not in the saint, as the saint has his own personality and a curve of his life journey as a bearer of the name. Hagiographies point out a clear expression of the spiritual meaning of the name by the saints... A name is seen by the church as a specific spiritual standard of a personal being, as an idea... And still, a name is ontologically primary, while its bearer, let it be a saint, is secondary; God himself had been prepared a name from eternity brought by an Angel long before He was conceived..."”3. For Nicholas II and his family Yekaterinburg became a wheel of tortures. In this battle, the Tsar Nicholas II the Passion Bearer overcame the city, just like the faith of the Holy Great Martyr Catherine overcame the torture wheel. Just like Jerusalem, Yekaterinburg shall take the sin of regicide. Just like Jerusalem, Yekaterinburg shall prove that a Man is stronger than the city. The 
torture wheel shall spin within the city, the people of Yekaterinburg will always remember and bear what happened here in the year 1918. Memories and suffering make the people's consciousness sober, but pain does not prevent the people's love for the city. It is easy to love something powerful; it's harder to love something when it's neglected. Maybe this trauma makes Yekaterinburg so alive.

Yekaterinburg the symbol-name has one "hollow" enemy, Yekaterinburg the sign. A symbol and a sign are often seen as synonyms, but every attentive person may notice that a symbol and a sign are different things. A symbol cannot be sold, but signs can. A crucifix, a gift from a beloved one or a dear memory cannot be sold. It is only the form, the shell that can be sold. A symbol brings people together; signs create social strata, as their task is to divide, to distinguish some objects, people, or phenomena. Yekaterinburg as a sign is a city among other cities; it is not the only one, it is one of many others, and it makes it impersonal, obscure for understanding. When the
Little Prince saw five thousand roses in the garden, he felt miserable. "I thought that I was rich, with a flower that was unique in all the world; and all I had was a common rose"14. He lay on the grass and cried. It always happens when the connection with the symbolic reality is lost. It is a mistake to think that a city name is random, that it is not related to the core of the city; it limits the symbol to the status of a social network avatar.

Thus, a city is a manifested name of the city, expressed and materialized, presented meaning of this name. The city speaks to us, it speaks its own language, actively and dynamically; we live it and understand it. In the name it matches us completely, down to the ground. "Those are the names, not the things that we love, those are the names, not the things that we hate, and should we die for it, we do it "in the name of something"" 15 . Of course, everything said above is just an approach to a symbol, which is endless. A symbol is similar to continuous spinning around one and only topic, for this reason the symbol of Yekaterinburg can be read, deciphered, and analysed endlessly.

Plato (1990) Kratil [Cratylus]. Collected works in 4 volumes, Volume 1. Moscow: Mysl', p. 630.

2 Lotman, M.Iu. (1993) Izvrannye stat'i v 3-kh tomakh [Collected Works in Three Volumes], Volume 3. Tallinn: Alexandra, p. 205.

3 Korepanov, N., Blinov, V. (2005) Gorod poseredine Rossii [A City in the Centre of Russia]. Yekaterinburg, Sokrat, p.7.

4 Mamin-Sibiryak, D.N. (1951) Gorod Ekaterinburg. Istoricheskiy ocherk [The City of Yekaterinburg. A Historical Sketch], In: Collected Works in 12 Volumes. Sverdlovsk: Oblgiz, Volume 12, p. 239.

5 Florenskiy, P.A. (1990) Imena [Names], In: Opyty: Literaturno-filosofskiy ezhegodnik [Experiments: Annals on Literature and Philosophy]. Moscow, Sovetskiy Pisatel', p. 363.

6 Losev, A.F. (2008) Veshch i imia. Samoe samo [Thing and Name. The Core of the Core] Saint Petersburg, Izdatel'stvo Olega Obyshko, p. 38.

7 Ivanov, A. (2014) Ioburg: gorod khrabrykh, sdelano v devianostye ["Yoburg": the City of the Brave Made in the Nineties]. Moscow, AST: Redaktsiia Eleny Shubinoy. P. 136

8 Husssel, E. (1996) Nachalo geometrii. Vvedenie Zhaka Derrida [Origin of Geometry: An Introduction by Jacques Derrida] Moscow: AdMarginem, p. 60.

9 Husserl, E. (1996) Nachalo geometrii. Vvedenie Zhaka Derrida [Origin of Geometry: An Introduction by Jacques Derrida] Moscow: AdMarginem, p. 63

10 Man'kova, I.L. (2000) Khram v serdtse i pamiati (ocherki istorii ekaterinburgskogo Ekaterininskogo sobora) [Temple in the Heart and Mind (sketches on the history of St. Catherine's Church of Yekaterinburg)], Yekaterinburg, 144 p.

11 Life and Sufferings of the Great Holy Martyr Catherine. sudogda.ru>life/ekaterin.htm

12 Words of prayer to St. Catherine: “... and ask for divine wisdom for us, thy slaves"

13 Florenskiy, P.A. (1990) Imena [Names], In: Opyty: Literaturno-filosofskiy ezhegodnik [Experiments: Annals on Literature and Philosophy]. Moscow, Sovetskiy Pisatel', p. 367-368.

14 Antoine de Saint Exupéry (2008) Malen'kiy Prints [The Little Prince]. Moscow, Eksmo, p. 72.

15 Losev, A.F. (2008) Veshch i imia. Samoe samo [Thing and Name. The Core of the Core] Saint Petersburg, Izdatel'stvo Olega Obyshko, p. 36. 


\section{К расшифровке имени Екатеринбурга}

\section{Л.С. Чернов ${ }^{\mathrm{a}}$ Е.Ю. Погорельская ${ }^{\sigma}$}

a Уральский институт управления РАНХиГС Россия, 620063, Екатеринбург, ул. 8 Марта, 66

${ }^{\sigma}$ Гуманитарный университет г. Екатеринбурга Россия, 620049, Екатеринбург, ул. Студенческая, 19

В статье город Екатеринбург представлен через своё имя; авторы показывают глубинную метафизическую связь имени города с историческими событиями и фактами истории Екатеринбурга. Город здесь видится как живой организм и личность. Часть работы является иконографической и семиотической иллюстраичей общих положений работы.

Ключевые слова: Екатеринбург, символ, имя, мастерство, святая Екатерина, город-крепость, идеальный город, икона Екатерины, пряха, обручение с Христом.

Научная специальность: 24.00.01 - теория и история культуры. 